\title{
Optimum timing in creatine supplementation for improved sporting performance
}

\author{
José Manuel Jurado-Castro1*, Ainoa Navarrete-Pérez², Antonio Ranchal-Sánchez ${ }^{3,4}$, Fernando Mata Ordóñez ${ }^{5}$ \\ 'Unidad de Metabolismo elnvestigación Pediátrica. Instituto Maimónides de Investigación Biomédica de Córdoba (IMIBIC). Hospital Universitario Reina Sofía. Universidad de Córdoba. \\ ${ }^{2}$ Grupo de investigación Neuroplasticidad y Estrés Oxidativo. Departamento de Bioquímica y Biología Molecular. Instituto Maimónides de Investigación biomédica de Córdoba \\ (IMIBIC). Universidad de Córdoba. ${ }^{3}$ nstituto Maimónides de Investigación Biomédica de Córdoba (IMIBIC). Hospital Universitario Reina Sofía. Universidad de Córdoba. ${ }^{4}$ Depar- \\ tamento de Enfermería, Farmacología y Fisioterapia, Facultad de Medicina y Enfermería. Universidad de Córdoba. ${ }^{5}$ CEAN, Centro de Estudios Avanzados en Nutrición. Córdoba.
}

doi: 10.18176/archmeddeporte.00026

Received: $15 / 05 / 2020$

Accepted: 03/10/2020

Key words:

Creatine. Sport.

Dietary Supplements.

Athletic performance.

\section{Summary}

Creatine is a sports supplement with high scientific evidence on its effects on performance and with emerging health's results, including for vegetarian athletes and older adults. The creatine type and effective doses have been well studied, presenting consistent results. However, not many studies have evaluated the ingestion timing in terms of its interaction with the creatine effects. The aim of this review is to analyze the different existing scientific literature on creatine supplementation protocols and their interaction with the timing of ingestion, in order to assess whether there is a greater effect of the ergogenic dose of creatine considered effective when It is ingested before, post workout or at another time of the day. The results of this work presented different types of protocols and doses in creatine supplementation, despite being diverse the protocols shown in the literature, the most effective consisted of a consumption of $0.3 \mathrm{~g} / \mathrm{kg} / \mathrm{d}$ for five days, followed by a consumption of 0.03 $\mathrm{g} / \mathrm{kg} / \mathrm{d}$, thus achieving a greater reserve of $\mathrm{PCr}$ in skeletal muscle. Studies showed greater benefits when creatine intake was carried out in the moments close to workout due to greater blood flow, the studies pointing to significant improvements in post-workout consumption, since creatine can increase the rate of glycogen uptake in muscle and increase insulin sensitivity.
Palabras clave:

Creatina. Deporte. Suplementos dietéticos. Rendimiento deportivo.

\section{Timing óptimo en la suplementación con creatina para la mejora del rendimiento deportivo}

\begin{abstract}
Resumen
La creatina es un suplemento deportivo con una elevada evidencia científica sobre sus efectos en el rendimiento y con resultados emergentes en la salud, incluida la de deportistas vegetarianos y adultos mayores. El tipo de creatina y las dosis efectivas, han sido bien estudiadas presentando resultados consistentes. Sin embargo, no son muchos los estudios que han evaluado el momento de la ingesta en cuanto a su interacción con los efectos de la creatina. El objetivo de esta revisión, es analizar la diferente literatura científica existente sobre los protocolos de suplementación con creatina y su interacción con el momento de la ingesta, con el fin de evaluar si existe un efecto mayor de la dosis ergogénica considerada efectiva de creatina cuando esta es ingerida antes, después del entrenamiento o en otro momento del día. Los resultados de este trabajo presentaron diferentes tipos de protocolos y dosis en la suplementación con creatina, a pesar de ser diversos los protocolos mostrados en la literatura, el más efectivo constó de un consumo de $0,3 \mathrm{~g} / \mathrm{kg} / \mathrm{d}$ durante cinco días, seguido de un consumo de 0,03 $\mathrm{g} / \mathrm{kg} / \mathrm{d}$ consiguiendo de esta forma, una mayor reserva de $\mathrm{PCr}$ en el músculo esquelético. Los estudios mostraron mayores beneficios cuando la ingesta de creatina se realizó en los momentos cercanos al entreno debido al mayor flujo sanguíneo, apuntando los estudios a mejoras significativas en un consumo post-entreno, debido a que la creatina puede aumentar la formación de de glucógeno en el músculo y aumentar la sensibilidad a la insulina.
\end{abstract}




\section{Introduction}

The use of sports supplements (SS) in sport is considerably widespread. In a recent study performed on Spanish athletes from different modalities, it was observed that $64 \%$ of them had consumed SS1. The reasons behind athletes taking SS are diverse, with the main reported motivation being to improve performance, according to scientific literature ${ }^{2}$. With the aim of finding ways to improve performance, there are some ergogenic aids, such as creatine monohydrate (CrM) with a high level of evidence. In this respect, recently the International Olympic Committee ${ }^{2}$ took a positioning in which it assessed the different SS and their degree of evidence, in which creatine $(\mathrm{Cr})$ is considered a SS in Group A, i.e., with a high level of evidence as an ergogenic aid. Over eighty reviews report the ergogenic and therapeutic effect of $\mathrm{Cr}^{3}$. Various meta-analyses and systematic reviews ${ }^{4,5}$ support these affirmations, observing improvements in lower and upper body strength, in high intermittent intensity training (HIIT), muscle mass and recovery, though few studies indicate positive effects on aerobic performance ${ }^{6}$.

$\mathrm{Cr}$ (methylguanidoacetic acid) is a natural nitrogenous organic acid $^{7}$ which is synthesised endogenously in the liver, pancreas and kidneys from three amino acids: arginine, glycine and methionine, at 1-2 grammes of $\mathrm{Cr}$ per day ${ }^{8}$, as well as being contributed exogenously through food, which compensates for losses of approximately $2 \mathrm{~g} /$ day ${ }^{9}$. Once synthesised, $90 \%$ of the $\mathrm{Cr}$ is stored in the skeletal muscle in the form of phosphocreatine (PCr) (60\%) and free $\mathrm{Cr}(40 \%)^{10}$. The main action of the PCr is linked to the re-synthesis of ATP via the transfer of the phosphate group to ADP. The re-synthesis of ATP measured by the $\mathrm{PCr}$, allows for increased performance during short-duration high-intensity actions, in which the phosphagens channel is the main source of energy. Therefore, the effect of Cr supplementation has been viewed with particular interest in terms of improving performance in high-intensity exercises lasting less than 30 seconds, proving most evident where there are repeated periods of intense exercise, such as strength training, for example ${ }^{11}$. Furthermore, strength training combined with taking $\mathrm{Cr}$, allows for an increase in the intensity of the training, which entails greater adaptations and muscle mass gains ${ }^{12,13}$

Added to the amplifying effect of performance in these kinds of actions, the reaction catalysed by the creatine kinase enzyme has been seen to consume a hydrogen ion $(\mathrm{H}+)$, which can contribute to an intracellular buffering action during exercises that entail a high glycolytic pathway activity, and therefore, a lower drop in $\mathrm{pH}$ and of neuromuscular fatigue associated (Figure 1).

In terms of the Cr supplementations doses and protocols, a diverse and broad bibliography has been found, however, literary results regarding the most beneficial timing in terms of $\mathrm{Cr}$ consumption are not so abundant ${ }^{14}$. The main objective of this review is to analyse the different scientific literature available about $\mathrm{Cr}$ supplementation protocols and interaction with intake timing, with the aim of assessing whether there is a greater effect on the ergogenic dose of $\mathrm{Cr}$ considered effective when consumed before or after training, or at another time during the day.
Figure 1. Proposed mechanisms of creatine.

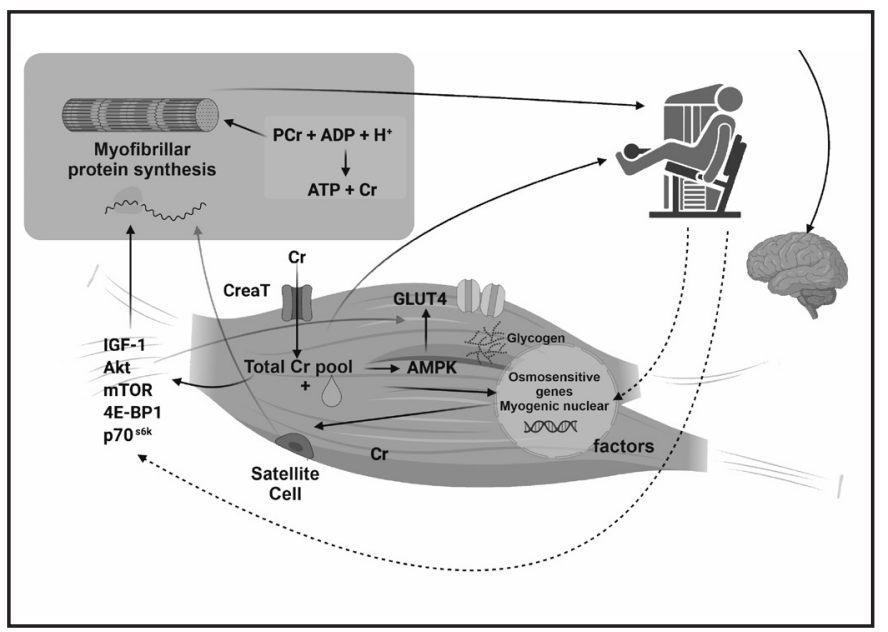

\section{Variables to consider in the responses to creatine supplementation}

The differences in response to supplementation, must be considered by the different professionals as part of the customisation of the diet and supplementation programme, taking into account variables such as the type of diet and age.

\section{Vegetarian or vegan diet}

$\mathrm{Cr}$ is found naturally in meat and fish, and in very small quantities in some vegetables, which means that due to the reduction or lack of intake of these food groups among vegetarians or vegans, Cr consumption is lowered or practically absent ${ }^{15}$. Furthermore, if vegan athletes do not introduce vitamin B12 supplementation into their diet, they may suffer a deficiency of this micro-nutrient, interfering with their endogenous synthesis of methionine, and with it, a lower biosynthesis of $\mathrm{Cr}^{16}$.

Among these demographics, it has been observed that the Cr content in different tissues, such as muscle, plasma, red blood cells, is lower than that of omnivores, though not in brain tissue ${ }^{17}$. Studies performed using an analysis of lateral vast muscle biopsy samples, have observed that total $\mathrm{Cr}$ levels $(\mathrm{Cr}+\mathrm{PCr})$ are lower in vegetarians than in omnivores, specifically: some $10-15 \%$ of the total; $7-10 \%$ of $\mathrm{PCr}$ and $7-26 \%$ of the $\mathrm{Cr}^{18}$. This could indicate that $\mathrm{CrM}$ supplementation could be of interest for athletes who follow this food pattern, because given the low levels of this amino acid on a muscle level, this could affect performance at high intensity due to the premature appearance of fatigue ${ }^{19}$. Likewise, the results from a recent systematic review ${ }^{18}$ reveal how $\mathrm{Cr}$ supplementation in vegetarians is effective in increasing $\mathrm{Cr}$ and $\mathrm{PCr}$ to higher levels than those obtained in omnivores. The minimum recommended intake for this demographic, is around $1 \mathrm{~g} / \mathrm{d}$ (amount equivalent to that found in one fillet of meat ${ }^{20}$. Therefore, $\mathrm{Cr}$ supplementation among vegetarians could be an efficient ergogenic aid to increase performance, with no 
current conclusive data available of how this effect may be greater than that observed in omnivores ${ }^{18}$.

\section{Age}

Despite the vast amount of literature available regarding the effectiveness of $\mathrm{Cr}$ supplementation in adult athletes, there is limited data in terms of children or teenagers. This lack of available literature is probably attributable to ethical restrictions, security issues and methodological challenges. Although its use in children and teenagers has commonly been discouraged ${ }^{21}$ there is no evidence of any dangers or adverse effects on this demographic ${ }^{22}$. In fact, the only clinically proven side effect is a 1-2 Kg weight increase, with no evidence that its short- or long-term use (as long as the $30 \mathrm{~g} / \mathrm{d}$ dosage over a period of 5 years is not exceeded) has negative effects on a healthy population from infancy to old age ${ }^{23}$.

Some studies have shown that $\mathrm{Cr}$ content reduces with age, what is not known is if this is due to low levels of physical activity or the ageing process ${ }^{24}$. Furthermore, the quantity and amount of Type II fibres diminishes progressively with age, with some studies ${ }^{25}$ observing that individuals with more type II fibres and a larger transversal session area, respond better to Cr supplementation, which can determine that older adults have an attenuated anabolic response to $\mathrm{Cr}$ supplementation?.

A recent review ${ }^{26}$ that assessed $\mathrm{Cr}$ supplementation combined with exercise on healthy older adults, reveals a positive effect with at least 12 weeks of resistance training. Its supplementation combined with moderate to high-intensity exercise in older people, would lead to an improvement in muscle health. This issue is particularly important in all countries with progressive ageing, given the special rate of morbidity associated with sarcopenia, such as fractures caused by falls, for example.

In addition to these benefits applicable to training and physical activity in older people, other benefits of $\mathrm{Cr}$ supplementation have been found, related to a greater capacity to reason quickly and think abstractly, known as "fluid intelligence", refuting double-blind tests performed on subjects of advanced age, who underwent memory tests ${ }^{27,28}$. A possible useful effect has also been associated, regarding spinal and bulbar muscular atrophy, as during the development of this pathology, there is a drop in intramuscular $\mathrm{Cr}$ levels, possibly related to the appearance of muscle weakness in these patients. Clinical trials are currently underway to assess the use of $\mathrm{Cr}$ as treatment for this pathology ${ }^{29}$. A relationship has also been observed between supplementing and an improvement in the state of health, despite ageing, with better lipid profile, lower growth of body fat compartment, and a reduction of oxidative stress and bone resorption among other effects ${ }^{30}$.

\section{Safety of creatine}

To date, not many studies have assessed the safety of $\mathrm{Cr}$ with a

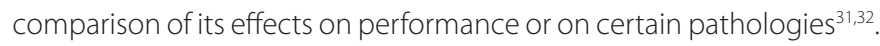
Studies about safety among males using CrM can be found in scientific literature, observing renal dysfunction, compartment syndrome in the legs, rhabdomyolysis, ischaemia cerebrovascular accident, atrial fibrillation, acute cholestatic hepatitis injury, and toxic hepatitis. However, this data has not been replicated with placebo controlled clinical trials ${ }^{3}$.

A recent study has assessed the adverse outcomes of CrM supplementing on non-pregnant post pubertal females, concluding that this supplement is safe for this demographic ${ }^{3}$. A similar conclusion to the results of other reviews performed on males or in mixed-sex studies, in which CrM taken within the dose and guidelines recommended by the different manufacturers and sporting-nutrition organisms around the world, appear to be safe, with no advantages revealed of using other forms of $\mathrm{Cr}^{31}$, which furthermore tend to have a higher market cost.

\section{Supplementation protocols and optimum consumption dose}

The study by Roger Harris et al. ${ }^{20}$ revealed how CrM supplementation increased muscular Cr content by around 20\%. Most of the studies with $\mathrm{Cr}$ commonly used a protocol based on the study by Hultman et al. ${ }^{33}$, in which they compared different protocols and discovered the most effective was supplementing with a load phase of 5-6 days, with a standard dose of $20 \mathrm{~g} / \mathrm{d}$ or $0.3 \mathrm{~g} / \mathrm{kg} / \mathrm{d}$, followed by a maintenance phase of 2 grammes a day or $0.03 \mathrm{~g} / \mathrm{kg} / \mathrm{d}$.

With regards to the $\mathrm{Cr}$ load protocol, a recent study performed on 17 trained males, revealed how intakes of $20 \mathrm{~g} / \mathrm{d}$ over 5 days combined with strength training, produced an increase in performance ${ }^{34}$. However, the vast majority of studies that have assessed the effects of Cr supplementation with the load and maintenance phase, have been performed on males. In the case of females, another trial has been carried out with the aim of assessing an increase in physical aptitude, performance or body composition, in response to four weeks of HIIT training combined with $\mathrm{Cr}$ supplementation. In this case, the initial supplementation was $0.3 \mathrm{~g} / \mathrm{kg} / \mathrm{d}$ over 5 days, followed by a maintenance phase of $0.1 \mathrm{~g} / \mathrm{kg} / \mathrm{d}$ for 23 days, combined with HIIT. The study concluded that the addition of $\mathrm{Cr}$ did not improve cardiorespiratory aptitude, nor did it improve the body composition of the females tested ${ }^{35}$. However, more studies are required that analyse the influence on both sex and gender of $\mathrm{Cr}$ supplementation.

The $\mathrm{Cr}$ load phase may increase body weight by approximately $2 \%$ due to an increase of intracellular water caused by the osmotic effect of the $\mathrm{Cr}^{36}$. It is important to advise that this effect is necessary as different studies have revealed the activation of specific osmosensitive genes in response to $\mathrm{Cr}$ supplementation, and therefore, it forms part of the action mechanism ${ }^{37}$.

In other supplementation protocols, an intake of only $0.1 \mathrm{~g} / \mathrm{kg} /$ day has been chosen, though this final protocol requires more days to cause an ergogenic effect ${ }^{38}$. In this respect, Galvan E, et al. ${ }^{32}$, performed a trial on 13 healthy and physically active adults, who were split into 4 groups, each supplemented with a different dosage of CrM $(1.5 \mathrm{~g}, 3 \mathrm{~g}, 5 \mathrm{~g}$ 
and placebo, respectively), with the aim of assessing the dependent effects of the doses on safety and performance rates of exercise. The authors conclude that up to $3 \mathrm{~g} /$ day is a safe and effective dose in terms of changes in strength and body composition.

Yáñez-Silva A, et al. ${ }^{39}$ performed a study on young elite football players with the aim of establishing the effects of CrM supplementation on muscle power. To do this, they used low consumption doses, with $0.03 \mathrm{~g} / \mathrm{kg} / \mathrm{d}$ for 14 days. The footballers were split into two groups, with one group consuming $\mathrm{Cr}$ the other a placebo. This was also a double-blind study. The anaerobic Wingate test was used to measure the results. Significant improvements were observed comparing power before and after the supplementation period. The placebo group also obtained improvements (influenced by training or external factors), but not as significant as those in the group that consumed $\mathrm{Cr}$.

Another study performed on men40 examined the effect of the so-called "load phase", analysing two methods of dosing daily intake. The subjects were split into two groups, and over 5 days they consumed $\mathrm{CrM}$, the first group taking $4 \times 5 \mathrm{~g} / \mathrm{d}$ and the second group consuming $20 \times 1 \mathrm{~g} / \mathrm{d}$, which obtained a lower urinary excretion of $\mathrm{Cr}$ and methylamine, leading to an estimated increase of $\mathrm{Cr}$ in the entire body and most probably in the muscle. The authors concluded that an intake of small doses, distributed evenly throughout the day, generated an improvement in the body and muscle retention of $\mathrm{Cr}$.

\section{Optimum timing in creatine supplementation}

Attempts have been made to clarify the optimum timing for $\mathrm{Cr}$ consumption, however, studies to this effect are more limited (Table 1) compared to those performed for other supplements ${ }^{14,41}$.
Regarding the most beneficial timing for Cr consumption, most studies take Antonio y Ciccone ${ }^{42}$ as reference, in which they compare the effects of supplementing before and after training. 19 body-building males participated in this study, competing 5-day programmed training for 4 weeks. The study showed that consuming 5 gr of CrM post-training, generated greater benefits in strength and improvements to body composition compared to pre-training consumption.

In a later study performed by Candow et. a ${ }^{43}$, they observed that 32 weeks of $\mathrm{Cr}$ supplementation $(0.1 \mathrm{~g} / \mathrm{kg}$ ) in healthy older adults (5071 years) immediately after strength training, led to greater lean mass compared to consumption immediately before exercise. However, the muscle strength increases produced by the $\mathrm{Cr}$ occurred regardless of the intake timing.

The observation from the Antonio y Ciccone ${ }^{42}$ study was not confirmed by the other study performed by Candow et al. ${ }^{44}$, whose aim was to compare the effects of $\mathrm{Cr}$ supplementation before $v$ s. after strength training exercise. This time, the sample constituted 22 healthy older adults ( 9 males, 13 females, between 50-64 years), performing strength training over 12 weeks ( 3 days a week). They were divided into two groups: with some consuming $\mathrm{Cr}$ before training and some after training, compared to a placebo group. During the 12-week training period, both groups experienced a significant increase in lean mass in the whole body, as well as an increase in strength in the lower and upper body without differences between groups. The authors concluded that changes in muscle mass or strength were similar regardless of the timing of consumption.

The same occurred in the study by Cooke et al. ${ }^{45}$, which assessed the effects of consuming $\mathrm{Cr}$ (with $5 \mathrm{~g}$ of additional carbohydrates) after exercise on body composition and muscle strength in 20 older adult males (55-70 years) over 12 weeks, participating in a programmed high

Table 1. Study characteristics about the optimum timing for sports supplementation with creatine.

\begin{tabular}{|c|c|c|c|c|c|c|c|}
\hline Author & $\begin{array}{l}\text { Participants } \\
\text { (Number/gen- } \\
\text { der/age) }\end{array}$ & $\begin{array}{l}\text { Type of } \\
\text { training }\end{array}$ & Supplement & Doses & Duration & $\begin{array}{l}\text { Time of taking } \\
\text { supplement }\end{array}$ & Results / Conclusions \\
\hline $\begin{array}{l}\text { Cribb and } \\
\text { Hayes (2006) }\end{array}$ & $\begin{array}{l}23 / \text { males / } 18 \\
-28 \text { years }\end{array}$ & $\begin{array}{l}\text { Strength } \\
\text { training }\end{array}$ & $\begin{array}{l}\text { Creatine }+ \\
\text { protein }+ \\
\text { glucose }\end{array}$ & $\begin{array}{l}1 \mathrm{~g} / \mathrm{kg} \\
(7 \mathrm{~g} / 100 \mathrm{~g} \\
\text { de creatine) }\end{array}$ & $\begin{array}{l}10 \\
\text { weeks }\end{array}$ & $\begin{array}{l}\text { Pre-training / } \\
\text { post-training vs } \\
\text { dawn / } \\
\text { dusk }\end{array}$ & $\begin{array}{l}\text { Greater muscle mass gain and } \\
\text { increases in muscle strength at } \\
\text { times near training }\end{array}$ \\
\hline $\begin{array}{l}\text { Antonio and } \\
\text { Ciccone (2013) }\end{array}$ & $\begin{array}{l}19 / \text { males / } \\
23.1 \pm 2.9 \text { years }\end{array}$ & Bodybuilding & Creatine & $5 \mathrm{~g}$ & $\begin{array}{l}4 \\
\text { weeks }\end{array}$ & $\begin{array}{l}\text { Pre-training vs. } \\
\text { post-training }\end{array}$ & $\begin{array}{l}\text { Improvement in strength and } \\
\text { body composition with post- } \\
\text { training consumption }\end{array}$ \\
\hline $\begin{array}{l}\text { Candow et al. } \\
\text { (2014) }\end{array}$ & $\begin{array}{l}22 \text { ( } 9 \text { males; } 13 \\
\text { females) / 50-64 } \\
\text { years }\end{array}$ & $\begin{array}{l}\text { Strength } \\
\text { training }\end{array}$ & Creatine & $0,1 \mathrm{~g} / \mathrm{kg}$ & $\begin{array}{l}12 \\
\text { weeks }\end{array}$ & $\begin{array}{l}\text { Pre-training vs. } \\
\text { post-training }\end{array}$ & $\begin{array}{l}\text { Changes in muscle mass or } \\
\text { strength similar regardless of } \\
\text { the timing of consumption. }\end{array}$ \\
\hline $\begin{array}{l}\text { Candow et. al } \\
(2015)\end{array}$ & $\begin{array}{l}64 \text { / (38 females; } \\
26 \text { males) / 50-71 } \\
\text { years }\end{array}$ & $\begin{array}{l}\text { Strength } \\
\text { training }\end{array}$ & Creatine & $0,1 \mathrm{~g} / \mathrm{kg}$ & $\begin{array}{l}32 \\
\text { weeks }\end{array}$ & $\begin{array}{l}\text { Pre-training } \\
\text { creatine vs. } \\
\text { post-training } \\
\text { creatine vs. } \\
\text { pre- and post- } \\
\text { training placebo }\end{array}$ & $\begin{array}{l}\text { Increases in muscle mass with } \\
\text { post-training creatine. Increa- } \\
\text { ses in muscle strength with } \\
\text { creatine regardless of timing. }\end{array}$ \\
\hline
\end{tabular}


intensity strength training plan. After the initial 7-day "load" phase, participants received instructions to take the supplement within 60 minutes after exercise. Taking CrM after exercise did not provide a greater improvement in body composition and muscle strength than the strength training alone. Although this study did not compare different timing of supplement consumption, these results should be considered in this review.

The aim of another study ${ }^{46}$ was to examine the effects of supplementation before and after training, with supplementation at another time of the day (morning and night) on muscle hypertrophy, strength and body composition, in a 10-week strength programme, demonstrating greater muscle mass gains and muscle strength increases when the supplement was taken around the time of training. In this case the supplement contained protein, $\mathrm{Cr}$ and glucose.

One review ${ }^{14}$ focused on assessing the effect of the timing of $\mathrm{Cr}$ consumption on muscle hypertrophy and strength, including some of the studies described linked to timing in our review, and although to date this literature is limited, it appears that Cr supplementation before and after resistance training sessions increases the mass and strength of lean tissue. The review suggests that taking $\mathrm{Cr}$ after training, provides greater muscular benefits than when it is taken prior to training ${ }^{14}$. Taking this supplement around the time of training may be more beneficial than taking $\mathrm{Cr}$ at another time of day, due to the increased blood flow and the sodium-potassium pump activation ${ }^{46}$ following the entry of Crinto the muscle.

In turn, studies are required that demonstrate the influence of circadian rhythms on $\mathrm{Cr}$ supplement timing, to discover the effects on performance in morning versus evening training.

\section{Conclusion}

The most effective $\mathrm{Cr}$ supplementation protocol comprised the consumption of $0.3 \mathrm{~g} / \mathrm{kg} / \mathrm{d}$ over five days, followed by a consumption of $0.03 \mathrm{~g} / \mathrm{kg} / \mathrm{d}$, thus achieving a better $\mathrm{PCr}$ reserve in the skeletal muscle.

The studies revealed greater benefits when the Cr consumption was performed around training times, due to greater blood flow, with studies indicating significant improvements in post-training consumption, as $\mathrm{Cr}$ may increase the formation of glycogen in the muscle and increase sensitivity to insulin.

\section{Conflict of interest}

The authors claim to have no conflict of interest whatsoever.

\section{Bibliography}

1. Baltazar-Martins G, Brito de Souza D, Aguilar-Navarro M, Muñoz-Guerra J, Plata MDM, Del Coso J. Prevalence and patterns of dietary supplement use in elite Spanish athletes. J Int Soc Sports Nutr. 2019;16:30. doi:10.1186/s12970-019-0296-5

2. Maughan RJ, Burke LM, Dvorak J, Larson-Meyer DE, Peeling P, Phillips SM, et al. IOC consensus statement: dietary supplements and the high-performance athlete. $\mathrm{Br} J$ Sports Med. 2018;52:439-55. doi:10.1136/bjsports-2018-099027
3. de Guingand DL, Palmer KR, Bilardi JE, Ellery SJ. Acceptability of dietary or nutritional supplementation in pregnancy (ADONS) - Exploring the consumer's perspective on introducing creatine monohydrate as a pregnancy supplement. Midwifery. 2020;82:102599. doi:10.1016/j.midw.2019.102599

4. Chilibeck PD, Kaviani M, Candow DG, Zello GA. Effect of creatine supplementation during resistance training on lean tissue mass and muscular strength in older adults: a meta-analysis. Open Access J Sports Med. 2017;8:213-26. doi:10.2147/OAJSM.S123529

5. Lanhers C, Pereira B, Naughton G, Trousselard M, Lesage FX, Dutheil F. Creatine Supplementation and Lower Limb Strength Performance: A Systematic Review and Meta-Analyses. Sports Med. 2015;45:1285-94. doi:10.1007/s40279-015-0337-4

6. Santesteban Moriones V, Ibáñez Santos J. Ayudas ergogénicas en el deporte [Ergogenic aids in sport]. Nutr Hosp. 2017;34:204-215. Published 2017 Feb 1. doi:10.20960/nh.997

7. Wyss M, Kaddurah-Daouk R. Creatine and creatinine metabolism. Physiol Rev. 2000;80:1107-13. doi:10.1152/physrev.2000.80.3.1107

8. Terjung RL, Clarkson P, Eichner ER, Greenhaff PL, Hespel PJ, Israel RG, et al. American College of Sports Medicine roundtable. The physiological and health effects of oral creatine supplementation. Med SciSports Exerc. 2000;32:706-17. doi:10.1097/00005768200003000-00024

9. Candow DG, Forbes SC, Chilibeck PD, Cornish SM, Antonio J, Kreider RB. Variables Influencing the Effectiveness of Creatine Supplementation as a Therapeutic Intervention for Sarcopenia. Front Nutr. 2019;6:124. doi:10.3389/fnut.2019.00124

10. Greenhaff PL. The nutritional biochemistry of creatine. The Journal of Nutritional Biochemistry. 1997;8(11):610-8.

11. Rawson ES, Miles MP, Larson-Meyer DE. Dietary Supplements for Health, Adaptation, and Recovery in Athletes. Int J Sport Nutr Exerc Metab. 2018;28:188-99. doi:10.1123/ ijsnem.2017-0340

12. Burke DG, Chilibeck PD, Parise G, Candow DG, Mahoney D, Tarnopolsky M. Effect of creatine and weight training on muscle creatine and performance in vegetarians. Med SciSports Exerc. 2003;35:1946-55. doi:10.1249/01.MSS.0000093614.17517.79

13. Kaviani M, Abassi A, Chilibeck PD. Creatine monohydrate supplementation during eight weeks of progressive resistance training increases strength in as little as two weeks without reducing markers of muscle damage. J Sports Med Phys Fitness. 2019;59:608-12. doi:10.23736/S0022-4707.18.08406-2

14. Forbes SC, Candow,DG. Timing of creatine supplementation and resistance training: a brief review. J. Exerc. Nutr. 2018;1:1-6

15. Rogerson D. Vegan diets: practical advice for athletes and exercisers. J Int Soc Sports Nutr. 2017;14:36. doi:10.1186/s12970-017-0192-9

16. Mahmood L. The metabolic processes of folic acid and Vitamin B12 deficiency.J. Health Res. Rev. 2014:1, 5

17. Yazigi Solis M, de Salles Painelli V, Giannini Artioli G, Roschel H, Concepción Otaduy M, Gualano B. Brain creatine depletion in vegetarians? A cross-sectional ${ }^{1} \mathrm{H}$-magnetic resonance spectroscopy ('H-MRS) study. Br J Nutr. 2014;111:1272-4. doi:10.1017/ S0007114513003802

18. Kaviani M, Shaw K, Chilibeck PD. Benefits of Creatine Supplementation for Vegetarians Compared to Omnivorous Athletes: A Systematic Review. Int J Environ Res Public Health. 2020;17:3041. doi:10.3390/ijerph17093041

19. Venderley AM, Campbell WW. Vegetarian diets : nutritional considerations for athletes. Sports Med. 2006;36:293-305. doi:10.2165/00007256-200636040-00002

20. Harris RC, Söderlund K, Hultman E. Elevation of creatine in resting and exercised muscle of normal subjects by creatine supplementation. Clin Sci (Lond). 1992;83(3):367-74. doi:10.1042/cs0830367

21. Greydanus DE, Patel DR. Sports doping in the adolescent: the Faustian conundrum of Hors de Combat. Pediatr Clin North Am. 2010;57:729-50. doi:10.1016/j.pcl.2010.02.008

22. Jagim AR, Stecker RA, Harty PS, Erickson JL, Kerksick CM. Safety of Creatine Supplementation in Active Adolescents and Youth: A Brief Review. Front Nutr. 2018;5:115.. doi:10.3389/fnut.2018.00115

23. Kerksick CM, Wilborn CD, Roberts MD, Smith-Ryan A, Kleiner SM, Jäger R, et al. ISSN exercise \&amp; sports nutrition review update: research \& recommendations. J Int SoC Sports Nutr. 2018;15:38

24. Rawson ES, Venezia AC. Use of creatine in the elderly and evidence for effects on cognitive function in young and old. Amino Acids. 2011;40:1349-62. doi:10.1007/ s00726-011-0855-9

25. Syrotuik DG, Bell GJ. Acute creatine monohydrate supplementation: a descriptive physiological profile of responders vs. nonresponders. J Strength Cond Res. 2004;18:610-7. doi:10.1519/12392.1

26. Stares A, Bains M. The Additive Effects of Creatine Supplementation and Exercise Training in an Aging Population: A Systematic Review of Randomized Controlled Trials. J Geriatr Phys Ther. 2020;43:99-112. 
27. McMorris T, Harris RC, Swain J, Corbett J, Collard K, Dyson RJ, et al. Effect of creatine supplementation and sleep deprivation, with mild exercise, on cognitive and psychomotor performance, mood state, and plasma concentrations of catecholamines and cortisol. Psychopharmacology (Berl). 2006;185:93-103. doi:10.1007/s00213-005-0269-z

28. Rae C, Digney AL, McEwan SR, Bates TC. Oral creatine monohydrate supplementation improves brain performance: a double-blind, placebo-controlled, cross-over trial. Proc Biol Sci. 2003;270:2147- 50 .

29. Hijikata Y, Katsuno M, Suzuki K, Hashizume A, Araki A, Yamada S, et al. Treatment with creatine monohydrate in Spinal and Bulbar Muscular Atrophy: protocol for a randomized, double-blind, placebo-controlled trial. JMIR Res Protoc. 2018;7:69.

30. Kreider RB, Kalman DS, Antonio J, Ziegenfuss TN, Wildman R, Collins R, et al. International Society of Sports Nutrition position stand: safety and efficacy of creatine supplementation in exercise, sport, and medicine. J Int Soc Sports Nutr. 2017;14:18. doi:10.1186/ s12970-017-0173-z

31. Jäger R, Purpura M, Shao A, Inoue T, Kreider RB. Analysis of the efficacy, safety, and regulatory status of novel forms of creatine. Amino Acids. 2011;40(5):1369-83. doi:10.1007/ s00726-011-0874-6

32. Galvan E, Walker DK, Simbo SY, Dalton R, Levers K, O'Connor A, et al. Acute and chronic safety and efficacy of dose dependent creatine nitrate supplementation and exercise performance. J Int Soc Sports Nutr. 2016;13:12

33. Hultman E, Söderlund K, Timmons JA, Cederblad G, Greenhaff PL. Muscle creatine loading in men. J Appl Physiol. 1996;81:232-37. doi:10.1152/jappl.1996.81.1.232

34. Law YL, Ong WS, GillianYap TL, Lim SC, Von Chia E. Effects of two and five days of creatine loading on muscular strength and anaerobic power in trained athletes. Strength Cond Res. 2009;23(3):906-914. doi:10.1519/JSC.0b013e3181a06c59

35. Forbes SC, Sletten N, Durrer C, Myette-Côté É, Candow D, Little JP. Creatine Monohydrate Supplementation Does Not Augment Fitness, Performance, or Body Composition Adaptations in Response to Four Weeks of High-Intensity Interval Training in Young Females. Int J Sport Nutr Exerc Metab. 2017;27:285-92. doi:10.1123/ijsnem.2016-0129

36. Häussinger D, Roth E, Lang F, Gerok W. Cellular hydration state: an important determinant of protein catabolism in health and disease. Lancet. 1993;341:1330-2. doi:10.1016/0140-6736(93)90828-5
37. Bemben MG, Lamont HS. Creatine supplementation and exercise performance: recent findings. Sports Med. 2005;35:107-25. doi:10.2165/00007256-200535020-00002

38. Cooper R, Naclerio F, Allgrove J, Jimenez A. Creatine supplementation with specific view to exercise/sports performance: an update. J Int Soc Sports Nutr. 2012;9:33.

39. Yáñez-Silva A, Buzzachera CF, Piçarro IC, Januario RS, Ferreira LH, McAnulty SR, et al. Effect of low dose, short-term creatine supplementation on muscle power output in elite youth soccer players. J Int Soc Sports Nutr. 2017;14:5

40. Sale C, Harris RC, Florance J, Kumps A, Sanvura R, Poortmans JR. Urinary creatine and methylamine excretion following $4 \times 5 \mathrm{~g} \times$ day(-1) or $20 \times 1 \mathrm{~g} \times$ day(-1) of creatine monohydrate for 5 days. J Sports Sci. 2009;27:759-66. doi:10.1080/02640410902838237

41. Naderi A, de Oliveira EP, Ziegenfuss TN, Willems MT. Timing, Optimal Dose and Intake Duration of Dietary Supplements with Evidence-Based Use in Sports Nutrition. J Exerc Nutrition Biochem. 2016;20:1-12

42. Antonio J, Ciccone V. The effects of pre versus post workout supplementation of creatine monohydrate on body composition and strength. J Int Soc Sports Nutr. 2013;10:36 doi:10.1186/1550-2783-10-36

43. Candow DG, Vogt E, Johannsmeyer S, Forbes SC, Farthing JP. Strategic creatine supplementation and resistance training in healthy older adults. App/ Physiol Nutr Metab. 2015;40:689-94. doi:10.1139/apnm-2014-0498

44. Candow DG, Zello GA, Ling B, Farthing JP, Chilibeck PD, McLeod K, et al. Comparison of creatine supplementation before versus after supervised resistance training in healthy older adults. Res Sports Med. 2014:22:61-74. doi:10.1080/15438627.2013.852088.

45. Cooke MB, Brabham B, Buford TW, Shelmadine BD, McPheeters M, Hudson GM, et al. Creatine supplementation post-exercise does not enhance training-induced adaptations in middle to older aged males. Eur J Appl Physiol. 2014;1 14:1321-32. doi:10.1007/ s00421-014-2866-1

46. Cribb PJ, Hayes A. Effects of supplement timing and resistance exercise on skeletal muscle hypertrophy. Med Sci Sports Exerc. 2006;38:1918-25. doi:10.1249/01 mss.0000233790.08788.3e 